\title{
Effect of vitamin D supplementation to prevent acute respiratory tract infection: an evidence-based case report
}

Received 15 April 2020

Accepted 30 July 2020

Link to DOI:

10.25220/WNJ.V04.i1.0002

Journal Website:

www.worldnutrijournal.org

\author{
Oki Y Oentiono ${ }^{1}$, Nurul Ratna $\mathrm{MM}^{1}$
}

1. Department of Nutrition, Faculty of Medicine, Universitas Indonesia, Dr. Cipto Mangunkusumo Hospital, Jakarta, Indonesia.

\begin{abstract}
Background: One of the frequent health problems that regularly occurs in Indonesia, as a tropical country is an acute respiratory tract infection, including influenza. Since immunological benefit of vitamin $D$ already proven, hypothetically, vitamin $D$ can be used as protective agent to prevent influenza or other respiratory tract infections.

Objectives: This evidence-based case report was focused on the evaluation of protective ability of vitamin D supplementation to prevent influenza or other acute respiratory tract infections.

Methods: Literature searching was conducted on PubMed data base and Cochrane Library using the related keyword combinations.

Results: Two randomized-clinical trials (RCTs) and a meta-analysis study were fulfilled the eligibility criteria. Vitamin $D$ supplementation did not reduce the incidence of influenza but reduce the incidence of non-influenza infection. High-dose vitamin D supplementation had no effect on the reduction of acute respiratory tract infection incidence. The meta-analysis concluded that vitamin D supplementation reduced the risk for acute respiratory tract infection and the stronger effects occurred on low-levels of vitamin D serum.

Conclusions: Vitamin D supplementation may prevent acute respiratory tract infections, especially in subjects with low-levels of vitamin D serum.

Keywords vitamin D, acute respiratory infection
\end{abstract}

\section{Introduction}

Acute respiratory tract infection was occurred on $46 \%$ of population/years. Influenza were prevalent in a third of them. This health problem can affect people in all age-groups. ${ }^{1}$ As a tropical country, Indonesia has a greater risk for infectious disease, including acute respiratory tract infection. Fourteen percent of all severe acute respiratory tract infection

\section{Corresponding author:}

Nurul Ratna Mutu Manikam, MD

Department of Nutrition, Faculty of Medicine,

Universitas Indonesia

Email:nurul.ratna@hotmail.com is caused by influenza. The incidence is highest in childhood population. ${ }^{2}$

Various micronutrients are proposed to be protective role to prevent influenza or other acute respiratory tract infection, including vitamin $\mathrm{D}$. Vitamin D has various beneficial effect on immune responses. Several immune cells have receptor, hence be able to respond vitamin D. Vitamin D acts in autocrine or paracrine processes in $\mathrm{B}$ and $\mathrm{T}$ cells. It also enhanced the activities of macrophage and dendritic cells. Hypothetically, vitamin D supplementation can be used to prevent influenza or other acute respiratory tract infections. ${ }^{3,4}$ 


\section{Clinical Illustration}

A 30- years old woman came with her son age 5years old as patient of clinical nutrition outpatient department in General Hospital. She tells her physicians that some of her son's close friends in school had suffered from cough, rhinorrhea, and fever since a week ago. He routinely contacts with them during the school time. The mother worried that her son would be infected by his friends. She has vitamin $\mathrm{D}$ tablets in her house, so she was wondering could vitamin D supplementation prevent the disease?

\section{Clinical questions}

Could vitamin D supplementation prevent influenza or other acute respiratory tract infections among children ?

$\mathrm{P}$ : Children

I : Vitamin D supplementation

C: Placebo

O: Prevent influenza or acute respiratory tract infection incidence

\section{Methods}

Article searching was conducted on PubMed database and the Cochrane Library on April 7, 2020. The key words combination on Table 1 were used within the searching process. English systematic review, meta-analysis, clinical trial or observational study in the last five years: 1 January $2014-31$ December 2019 publication were included. The study with other specific medical conditions (such as pregnant, cancer, bowel disease) were not included. An animal study and non-relevance article were also excluded. Critical appraisal was conducted using critical appraisal tools for clinical trials and systematic review that published by The Center of Evidence-Based Medicine (CEBM)

\section{Results}

According to literature searching, with mentioned strategy, we obtained the literatures as presented number in Table 1 based on each key words combination. After duplicates removed, a total of 13 articles were recorded. Four of them were excluded due to other specific condition including pregnancy ( 2 studies), asthma ( 1 study), and bowel disease (1 study). The other six studies were excluded since not relevant topics. Finally, we obtained two randomized clinical trials and one-meta analysis.

From two tables above we can see that vitamin D can protect against respiratory non influenza infection better than respiratory influenza infection. We needed 93 patients treated with vitamin D to prevent 1 patient infected with influenza contrasted with non influenza patients which only need 17 patients treated to get the same results.

\section{Discussion}

Vitamin D expands the number of antimicrobial peptide cathelicidine in respiratory epithelium, which has been shown to reduce the severity of the disease and the replication of influenza virus in vitro. ${ }^{8}$ However we found a different result, vitamin $D$ can protect someone from non-influenza respiratory infection rather than influenza itself, this findings need further research. A combination of the aims of these clinical trials could answer two dissected-clinical questions. After the necessity of vitamin D supplementation to prevent influenza or acute respiratory tract infection, we also could know which dose to be used for it. The two included clinical trials showed an almost concordant conclusion. Loeb et $\mathrm{al}^{5}$ reported that vitamin D supplementation did not reduce the incidence of influenza, but significantly reduced non-influenza viral infection. On the other hand, Aglipay et $\mathrm{al}^{6}$ concluded the high-dose vitamin D supplementation did not reduce the incidence of viral respiratory tract infection, not specifically caused by influenza. The later also showed that compared to standard-dose vitamin D supplementation, the high-dose one had no difference in the median time to the first laboratory-confirmed infection and the number of laboratory-confirmed infections.

As a strength of these two clinical trials, the outcomes were confirmed validly and accurately. The cause of infections was diagnosed using polymerases chain reaction (RT-PCR). Both clinical trials also described the distribution of infection causes. The two clinical trials had a similar limitation. Loeb et $\mathrm{al}^{5}$ had subjects with highbaseline vitamin D levels among the two groups. 
Meanwhile, Aglipay et $\mathrm{al}^{6}$ started the study early of the winter. Probably, it implicates the lack of effect of high-dose vitamin D supplementation due to high-baseline vitamin D serum level at the end of the summer was relatively high. Another limitation, due to restricted by ethical consideration, the clinical trial conducted by Aglipay did not compare the intervention group to placebo.

The meta-analysis study confirmed the effect of vitamin $\mathrm{D}$ supplementation to reduce the incidence of acute respiratory tract infection. Vitamin D supplementation is a protective factor for all-cause of acute respiratory tract infection based on the adjusted odds ratio of 0.88 . The meta-analysis also concluded that the protective effects of vitamin D supplementation were stronger in patients with low baseline vitamin $\mathrm{D}$ serum levels $(<25 \mathrm{nmol} / \mathrm{L}){ }^{7}$

The clinical trials and meta-analysis also had two similar limitations. First, they did not analyze the potential confounders such as baseline nutritional status and record of dietary patterns. Some studies revealed underweight, overweight, and obesity as independent risk factors for influenza. ${ }^{9,10}$ Second, three included studies also did not analyzed the level of patient adherence on each study.

\section{Conclusion}

According to two clinical trials and one metaanalysis, vitamin D supplementation neither reduce nor prevent influenza. However, high-dose of vitamin D supplementation may protect noninfluenza respiratory tract infection in patients with low-vitamin D serum levels. 
Table 1. Keyword and the numbers of included-articles

\begin{tabular}{|c|c|c|c|}
\hline \multirow{2}{*}{ Database } & \multirow{2}{*}{ Terminology } & \multicolumn{2}{|c|}{ Number of article(s) } \\
\hline & & Hits & Included \\
\hline Pubmed & $\begin{array}{l}\text { "vitamin D supplementation" AND “influenza" AND } \\
\text { "prevention" }\end{array}$ & 6 & 2 \\
\hline Pubmed & $\begin{array}{l}\text { "vitamin D supplementation" AND "influenza-like illness" } \\
\text { AND "prevention" }\end{array}$ & 0 & 0 \\
\hline Pubmed & $\begin{array}{l}\text { "vitamin D supplementation" AND "acute respiratory tract } \\
\text { infection" AND "prevention" }\end{array}$ & 1 & 1 \\
\hline Cochrane & $\begin{array}{l}\text { "vitamin D supplementation" AND “influenza” AND } \\
\text { "prevention" }\end{array}$ & 13 & 2 \\
\hline Cochrane & $\begin{array}{l}\text { "vitamin D supplementation" AND "influenza-like illness" } \\
\text { AND "prevention" }\end{array}$ & 0 & 0 \\
\hline Cochrane & $\begin{array}{l}\text { "vitamin D supplementation" AND "acute respiratory tract } \\
\text { infection" AND "prevention" }\end{array}$ & 0 & 0 \\
\hline
\end{tabular}

Table 2. Characteristics of each study

\begin{tabular}{|c|c|c|c|}
\hline & Loeb et al. ${ }^{5}$ & Aglipay et al. ${ }^{6}$ & Martineau et al. ${ }^{7}$ \\
\hline $\begin{array}{l}\text { Study Design (Levels } \\
\text { of evidence) }\end{array}$ & RCT (1B) & $\mathrm{RCT}(1 \mathrm{~B})$ & SR/MA (1A) \\
\hline Objective of the study & $\begin{array}{l}\text { To investigate the ability } \\
\text { vitamin D supplementation to } \\
\text { reduce influenza and other } \\
\text { upper viral respiratory tract } \\
\text { infections. }\end{array}$ & $\begin{array}{l}\text { To investigate whether high- } \\
\text { dose vs standard-dose } \\
\text { vitamin D supplementation } \\
\text { could prevent the wintertime } \\
\text { upper respiratory tract } \\
\text { infections in young children. }\end{array}$ & $\begin{array}{l}\text { To assess the overall effect of } \\
\text { vitamin D supplementation on } \\
\text { risk of acute respiratory tract } \\
\text { infection. }\end{array}$ \\
\hline Patients (subjects) & $\begin{array}{l}\text { Children and adolescents aged } \\
\text { 3-17 years in Thanh Liem } \\
\text { District of Vietnam. }\end{array}$ & $\begin{array}{l}\text { Young children aged 1-5 } \\
\text { years in Toronto, Canada. }\end{array}$ & $\begin{array}{l}\text { Broad range of age in total } \\
\text { analysis. }\end{array}$ \\
\hline $\begin{array}{l}\text { Intervention and } \\
\text { Comparison }\end{array}$ & $\begin{array}{l}\text { Vitamin D ( } 14.000 \mathrm{IU} / \text { week) } \\
\text { versus placebo during } 8 \\
\text { months. }\end{array}$ & $\begin{array}{l}\text { High dose (2000 IU) versus } \\
\text { standard dose ( } 400 \mathrm{IU}) \\
\text { supplementation of vitamin D } \\
\text { during } 4-8 \text { months }\end{array}$ & $\begin{array}{l}\text { Vitamin D supplementation } \\
\text { ( } 400 \mathrm{IU}-30.000 \mathrm{IU}) \text { versus } \\
\text { placebo. }\end{array}$ \\
\hline $\begin{array}{l}\text { Number of Subjects } \\
\text { (or study for meta- } \\
\text { analysis) }\end{array}$ & 650 vs. 650 subjects & 349 vs. 354 subjects & $\begin{array}{l}25 \text { RCT studies with } 11.321 \\
\text { total of subjects. }\end{array}$ \\
\hline Outcomes & $\begin{array}{l}\text { The incidence of influenza } \\
\text { between supplemented } \\
\text { subjects was not different } \\
\text { to placebo (7.7\% vs } 6.6 \% \text {, } \\
\text { Hazard ratio. [HR]: } 1.18 \text {, } \\
\text { 95\% CI: } 0.79-1.78) \text {. } \\
\text { Vitamin D supplemented } \\
\text { subjects had a lower } \\
\text { incidence of non-influenza } \\
\text { respiratory tract infection } \\
(22.5 \% \text { vs } 28.5 \%, \text { HR } \\
0.76,95 \% \text { CI: } 0.61-0.94)\end{array}$ & $\begin{array}{l}\text { There was no difference } \\
\text { in the number of } \\
\text { laboratory-confirmed } \\
\text { infections among the } \\
\text { groups. (RR, 0.97; } 95 \% \\
\text { CI, 0.80-1.16). } \\
\text { There was no difference } \\
\text { in the median time to the } \\
\text { first laboratory- } \\
\text { confirmed infection: } 3.95 \\
\text { vs } 3.29 \text { months. } \\
\text { Vitamin D did not reduce } \\
\text { the occurrence of non- } \\
\text { influenza respiratory } \\
\text { tract infection (RR: } 1.01 \text {; } \\
\text { 95\% CI } 0.83 \text { to } 1.23 \text { ). }\end{array}$ & $\begin{array}{l}\text { Vitamin D } \\
\text { supplementation can } \\
\text { reduce the risk of acute } \\
\text { respiratory tract infection. } \\
\text { (adjusted odds ratio: } 0.88 \text {, } \\
\text { 95\% CI 0.81-0.96). } \\
\text { Protective effects of } \\
\text { vitamin D } \\
\text { supplementation were } \\
\text { stronger in patient with } \\
\text { low baseline vitamin D } \\
\text { serum level }(<25 \mathrm{nmol} / \mathrm{L}) \text {. }\end{array}$ \\
\hline
\end{tabular}


Table 2. Characteristics of each study (continued)

\begin{tabular}{|c|c|c|c|}
\hline & Loeb et al. ${ }^{5}$ & Aglipay et al. ${ }^{6}$ & Martineau et al. ${ }^{7}$ \\
\hline Limitation & $\begin{array}{l}\text { At the baseline, vitamin D } \\
\text { serum level of the subjects } \\
\text { were not significantly different } \\
\text { but they had high level vitamin } \\
\text { D serum level. It makes the } \\
\text { different of occurrence were } \\
\text { not significantly different. }\end{array}$ & $\begin{array}{l}\text { The study conducted at the } \\
\text { early winter. The basal } \\
\text { vitamin D serum was high } \\
\text { due to peak level of vitamin } \\
\text { D serum was occurred in the } \\
\text { end of summer. }\end{array}$ & $\begin{array}{l}\text { The dose-related effect were } \\
\text { not accounted. } \\
\text { The outcomes measurement in } \\
\text { each study quietly different. }\end{array}$ \\
\hline Conclusion & $\begin{array}{l}\text { The incidence of influenza } \\
\text { were not reduced by vitamin D } \\
\text { supplementation. However, } \\
\text { vitamin D reduced moderately } \\
\text { non-influenza viral infection. }\end{array}$ & $\begin{array}{l}\text { Compared to standard dose, } \\
\text { high-dose of vitamin D } \\
\text { supplementation did reduced } \\
\text { viral respiratory tract } \\
\text { infection. }\end{array}$ & $\begin{array}{l}\text { Vitamin D supplementation } \\
\text { can prevent the overall acute } \\
\text { respiratory tract infection. }\end{array}$ \\
\hline
\end{tabular}

Table 3. Validity Assessment for RCTS by Loeb et al and Aglipay et al

\begin{tabular}{|c|c|c|}
\hline \multicolumn{3}{|c|}{ Are the results of this single preventive therapeutic trial valid? } \\
\hline Question & Loeb et al & Aglipay et al \\
\hline $\begin{array}{l}\text { Was the assignment of patient to } \\
\text { treatment randomised? And was the } \\
\text { randomisation list concealed? }\end{array}$ & $\begin{array}{l}\text { Yes, patients were randomly assigned } \\
\text { to either the experimental or placebo } \\
\text { control group. } \\
\text { Yes, the list was concealed, they use } \\
\text { external research organization to } \\
\text { ensure randomization and concealment } \\
\text { purpose. }\end{array}$ & $\begin{array}{l}\text { Yes, patients were randomly assigned } \\
\text { to either the high dose or standard dose } \\
\text { group. } \\
\text { Yes, the list was concealed. }\end{array}$ \\
\hline $\begin{array}{l}\text { Were all patents who entered the } \\
\text { trial accounted for at its conclusion? } \\
\text { And were they analysed in the group } \\
\text { to which they were randomised? }\end{array}$ & $\begin{array}{l}\text { This study used intention to treat } \\
\text { analysis. }\end{array}$ & $\begin{array}{l}\text { This study used intention to treat } \\
\text { analysis. }\end{array}$ \\
\hline $\begin{array}{l}\text { Were patients and clinicians kept } \\
\text { blind to which treatment was being } \\
\text { received? }\end{array}$ & Yes & Yes \\
\hline
\end{tabular}

\begin{tabular}{lll}
$\begin{array}{l}\text { Aside from the experimental } \\
\text { treatment, were the groups treated } \\
\text { equally? }\end{array}$ & Yes & Yes \\
$\begin{array}{lll}\text { Were the groups similar at the start } \\
\text { of the trial? }\end{array}$ & $\begin{array}{l}\text { Yes, we can check in the baseline } \\
\text { characteristics table. }\end{array}$ & $\begin{array}{l}\text { Yes, we can check in the baseline } \\
\text { characteristics table. }\end{array}$ \\
\hline
\end{tabular}




\section{Validity}

Table 4. Validity assessment of meta-analysis by Martineau et al Are the results of this systematic review of therapy valid?

Question
Is it a systematic review of randomised trials of the
treatment you're interested in?
Does it include a methods section that describes: finding
and including all the relevant trials?

\section{Martineau et al}

Yes.

\section{and including all the relevant trials?}

Yes, it is explained in the Methods subsection "study identification and selection, and data collection process". They included trials from any languages. They performed systematic search in major databases, but did not search unpublished material using handsearching method.

Assessing their individual validity?

Yes, quality of included studies were assessed using the Cochrane Collaboration risk of bias tool and five GRADE considerations (study limitations, consistency of effect, imprecision, indirectness, and publication bias).

Were the results consistent from study to study? Yes, vitamin D supplementation can reduce the risk of acute respiratory tract infection. (adjusted odds ratio: $0.88,95 \% \mathrm{CI}$ 0.81-0.96).

\section{Importance}

Table 4. Comparison of vitamin D and placebo on influenza infection

Intervention

Influenza infection

Vit D

Placebo

\begin{tabular}{lcc} 
Yes & 50 & 43 \\
No & 600 & 607 \\
\hline
\end{tabular}

Absolute Risk Reduction (ARR) $=\mathbf{1 \%}$

Number Needed to Treat $($ NNT $)=93$

Table 5. Comparison of Vitamin D and Placebo on Influenza Infection

Intervention

Non Influenza infection

Vit D

Placebo

Yes

146

185

No

504

465

$\mathrm{ARR}=6 \%$

NNT $=17$ 


\section{Applicability}

Table 6. Critical appraisal on the applicability

\begin{tabular}{|c|c|c|c|}
\hline & Loeb et al..$^{5}$ & Aglipay et al. ${ }^{6}$ & Martineau et al. ${ }^{7}$ \\
\hline $\begin{array}{l}\text { Resemblance of the } \\
\text { study subjects with the } \\
\text { case }\end{array}$ & $\begin{array}{l}\text { Children and adolescents aged } \\
\text { 3-17 years in Thanh Liem } \\
\text { District of Vietnam. } \\
\text { Resemblance is strong, since } \\
\text { the case is Indonesian kid age } 5\end{array}$ & $\begin{array}{l}\text { Young children aged 1-5 } \\
\text { years old in Toronto, Canada. } \\
\text { Moderate resemblance } \\
\text { because different race }\end{array}$ & $\begin{array}{c}\text { Low resemblance because, this } \\
\text { is a systematic review which } \\
\text { include age } 6 \text { months until } 80 \\
\text { years old patients. }\end{array}$ \\
\hline $\begin{array}{l}\text { Agreement to the } \\
\text { value and preference } \\
\text { in the community }\end{array}$ & \multicolumn{3}{|c|}{ Very likely to agree since vitamin D is well known among Indonesian population. } \\
\hline $\begin{array}{l}\text { Feasibility of the } \\
\text { therapy } \\
\text { in the setting of daily } \\
\text { clinical practice }\end{array}$ & \multicolumn{3}{|c|}{ Very feasible, vitamin D is easily found everywhere in the local drug store. } \\
\hline
\end{tabular}

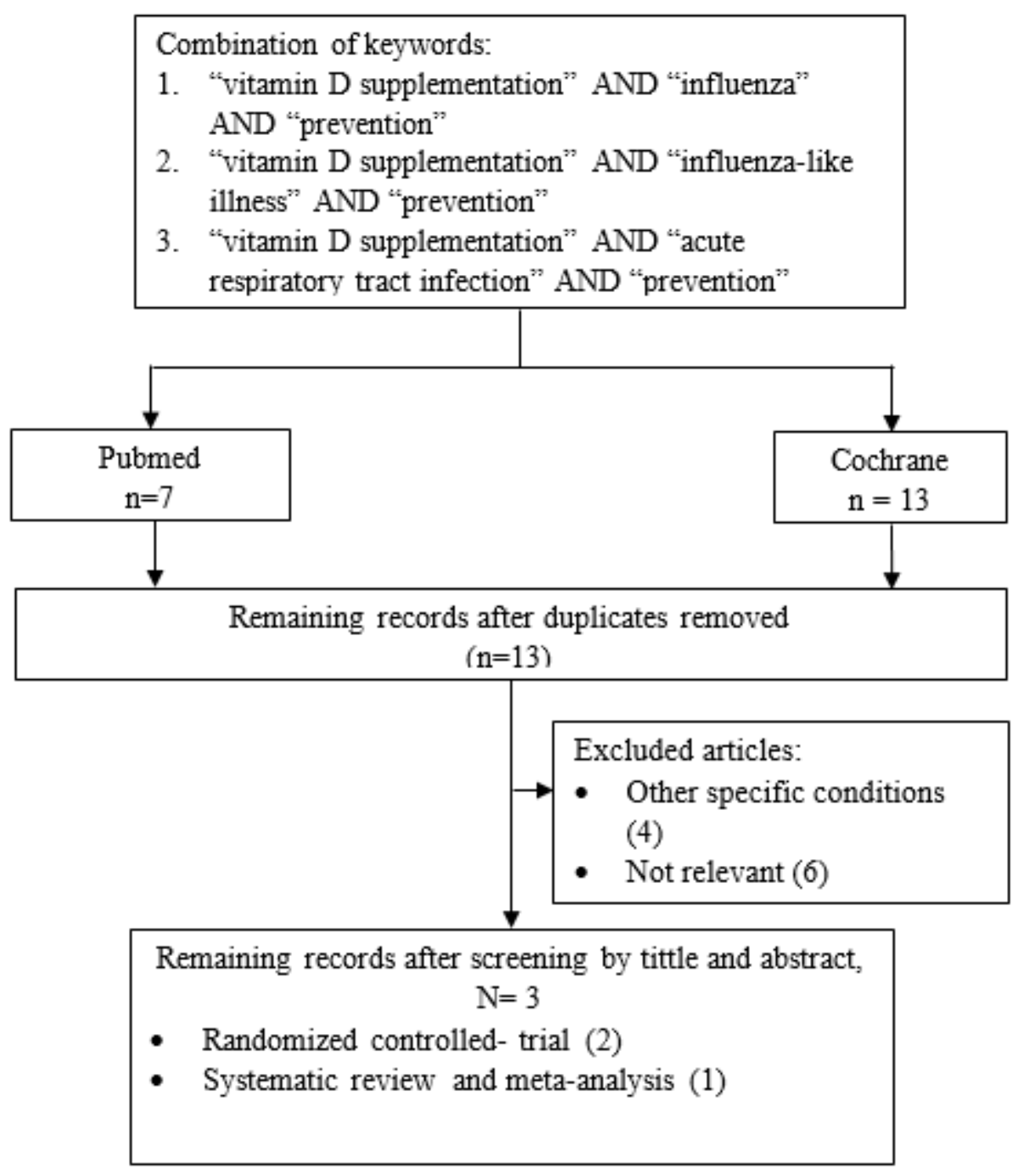

Figure 1. The PRISMA flowchart for the selection articles 


\section{Conflict of interest}

The authors declare no conflict of interest regarding this study.

\section{Open Access}

This article is distributed under the terms of the Creative Commons Attribution 4.0 International Licence

(http://creativecommons.org/licenses/by/4.0/), which permits unrestricted use, distribution, and reproduction in any medium, provided you give appropriate credit to the original author(s) and the source, provide a link to the Creative Commons license, and indicate if changes were made.

\section{References}

1. Puig-Barberà $\mathrm{J}$, Burtseva $\mathrm{E}, \mathrm{Yu} \mathrm{H}$, Cowling $\mathrm{BJ}$, Badur S, Kyncl J, et al. Influenza epidemiology and influenza vaccine effectiveness during the 20142015 season: annual report from the Global Influenza Hospital Surveillance Network. BMC Public Health. 2016 Aug 22;16 Suppl 1(Suppl 1):757.

2. Susilarini NK, Haryanto E, Praptiningsih CY, Mangiri A, Kipuw N, Tarya I, et al. Estimated incidence of influenza-associated severe acute respiratory infections in Indonesia, 2013-2016. Influenza Other Respi Viruses. 2017/12/05. 2018 Jan;12(1):81-7.

3. Aranow C. Vitamin D and the immune system. $J$ Investig Med. 2011;59(6):881-6.

4. Chirumbolo S, Bjørklund G, Sboarina A, Vella A. The Role of Vitamin D in the Immune System as a Pro-survival Molecule. Clin Ther. 2017 May 1;39(5):894-916.

5. Loeb M, Dang AD, Thiem VD, Thanabalan V, Wang B, Nguyen NB, et al. Effect of Vitamin D supplementation to reduce respiratory infections in children and adolescents in Vietnam: A randomized controlled trial. Influenza Other Respi Viruses. 2019 Mar;13(2):176-83.

6. Aglipay M, Birken CS, Parkin PC, Loeb MB, Thorpe K, Chen Y, et al. Effect of High-Dose vs Standard-Dose Wintertime Vitamin D Supplementation on Viral Upper Respiratory Tract Infections in Young Healthy Children. JAMA. 2017 Jul 18;318(3):245-54.

7. Martineau AR, Jolliffe DA, Hooper RL, Greenberg L, Aloia JF, Bergman P, et al. Vitamin D supplementation to prevent acute respiratory tract infections: systematic review and meta-analysis of individual participant data. BMJ. 2017 Feb;356:i6583.

8. Barlow PG, et al. Antiviral activity and increased host defense against influenza infection elicited by the human cathelicidin LL-37. PloS one. 2011;6(10)

9. Moser J-AS, Galindo-Fraga A, Ortiz-Hernández AA, Gu W, Hunsberger S, Galán-Herrera J-F, et al. Underweight, overweight, and obesity as independent risk factors for hospitalization in adults and children from influenza and other respiratory viruses. Influenza Other Respi Viruses. 2019 Jan;13(1):3-9.

10. Neidich SD, Green WD, Rebeles J, Karlsson EA, Schultz-Cherry S, Noah TL, et al. Increased risk of influenza among vaccinated adults who are obese. Int J Obes (Lond). 2017;41(9):1324-30. 